\title{
Cities for People: The Dependency \& Impact of Automobile in the Life of City Dwellers
}

\author{
By Francis O. Okeke ${ }^{1 *}$, Andy E. Okosun ${ }^{2}$, Clifford A. Udeh ${ }^{3}$, \\ Chukwumezie J. Okekeogbu***
}

\begin{abstract}
Just like the plough breaking the grounds, many Nigerian cities have been transformed by the use of automobile. Cars have reshaped public realms and remodelled the nation's landscape, creating a bizarre unpaved erstwhile versions of centuries ago. The rising dominance of automobile is well revealed by their imprints on the urban land use patterns. However, the invention of the massproduced automobile was a breakthrough in mobility and comfort; the modern consequences of its heavy use has led to a dramatic increase in accident death rates, the use of fossil fuels, social isolation, community disconnection, obesity, environmental pollution, urban sprawl and urban decay. This research, therefore provides an insight into some of the causes of over-dependence on automobile and its impact on the lives of city dwellers using Achara Layout in Enugu as a case study. The target goal is to proffer solution to remedy this obvious lack of foresight on urban transportation system. Using a descriptive research method that utilizes both primary and secondary data, the study through surveys, $\mathrm{x}$-rayed why the increase in automobile dependence. Furthermore, it reveals that although the use of automobile is advantageous, the consequence of over dependency is far more overwhelming. The research results note that four fundamental policies will address successfully and specifically automobile dependency imposed by local conditions. It concludes that the gross accommodation of urban land to automobile be redressed and the expensive sterility of excessive motorized traffic be eliminated and advocates for an eco-friendly alternative means of city transportation.
\end{abstract}

Keywords: Urban, Automobile Dependency, Planning, City Dwellers, Transportation.

\section{Introduction}

Transportation is the hallmark of every city's growth and development, the artery to which all land uses are accessed and the requisite for mobility. On the other hand, cities are vital entities that constantly grow and develop, if change takes place according to a plan designed to benefit the community, it makes a big difference to the quality of urban life. True quality in urban life and the attainment of an attractive living environment for people of all income level remains an unfulfilled but worthy goal as automobiles have hog our cities (Ronald, 1981). Cars are ubiquitous in most cities, as they are used for transportation to work, school, shop, recreation etc. They have monopolized the roads and moulded cityscape to suit their resolute demands, also seen as homes away from home and small sanctuaries for privacy, where chauffeurs relax with their thoughts alone. The invention of automobile is undeniably one of the most groundbreaking advancements in human technology but are also one of the biggest 
contributors to all kinds of pollution. The result of uncontrolled increased mobility can also be linked to a trend that is generally understood as urban sprawl, which is the widespread sub-urban growth and vice versa the reduction in city centers. Matt, (2014) defines an auto-dependent city as one that has developed in a way that makes it difficult or impossible for most people to access the city's amenities with reasonable convenience without a car. In an auto-dependent city, most individuals are auto-dependent. This study therefore, aim to investigate the impact of automobile in the life of city dwellers with specific objectives as follows:

i. To identify the causes of automobile dependency in major cities

ii. To highlight the indicators of an automobile dependent city

iii. To discuss the effects of automobile use on the urban environment.

iv. To proffer solutions on reducing dependency of automobile use in major cities.

\subsection{Background of study}

One of the critical problems facing the Nigerian cities has been that of deteriorating living conditions leading to increased death rate and diseases caused by pollution and poor sanitation. (Udeh \& Okeke, 2018). Every city dweller is familiar with congested streets and knows the intimidating force of four solid lanes of cars steadily flowing through a city centre. In some developed cities the experience of skyways, airbridge and concourses, with unhampered flow of pedestrians above and below the level of traffic is very dramatic. Subsequently, in all metropolitan regions of Nigeria, whether they are low density, sprawling cities such as Uyo or Jos, that are now almost entirely dependent on car and well-known for their auto-based environmental problems, or more transit-based high density cities such as Lagos or Abuja, with their gridlocked traffic and fume-filled air; urban policy is centrally concerned with how to better manage the automobile. The main implication is that street space belongs to automobile, people on the other hand, belong to buildings; invariably cities are for cars not for people.

However, it is not always accurately known to what extent the problem of automobile dependency has progressed and how cities really differ from each other in their basic transportation patterns (Kenworthy and Laube, 1999). While predictions vary, Thomas (2003) estimates that towards the middle of the 21 st century more than two-thirds of global population will be living in urban areas. In 2008 the hallmark was reached. Now, almost half of the world's population lives in cities and this number is projected to grow to around three-quarters by 2050 (Chad, 2017). In the early 1950s, the world's population stood at 2.6 billion. At the same time, 50 million cars were on the world's roads. By 2000, the world's population had risen to 6 billion, with 500 million vehicles in existence. It is estimated that the number of vehicles will reach 1 billion by 2050 (Gauzin-Müller, 2002). As postulated by Martin (2010), Modern cities are full of automobiles and other motorized vehicles, with one half of city's land mass dedicated to motorways, service stations, parking space, traffic infrastructures and automobile-related businesses. Also worthy of note is that, spaces reserved and apportioned for other forms of transport shrank and ultimately vanished. For example, in this automotive period, sidewalks that were normally considered necessary for separating pedestrians from different modes of transportation were less frequently designed and built along many 
urban roads and streets. Walking as a means of movement seems increasingly incidental as usual pedestrian and bike lanes found in many ancient cities, have become nonexistent and late-comers in present-day municipalities where viable forms of mobility have been trashed out by growing automobile reliance.

\section{Literature Review}

According to Newman \& Kenworthy, (1999) automobile dependence is when a city or an area of a city assumes automobile use as the dominant imperative in its decisions on transportation, infrastructure and land use. Other modes thus become increasingly peripheral, marginal or non-existent until there are no real options for passenger travel other than the automobile. The opposite of automobile dependency is a balanced transportation system with more mixed travel patterns. While no clear or consistent definition of car dependency exists, some scholars and practitioners have attempted to address the question of how environmental sustainability is affected by vehicle dependence. Newman and Kenworthy, (1999) opined that "Automobile dependence is the primary force driving cities to increase the use of land, energy, water (both greenhouse gases and local smog related emissions), traffic noise and stormwater pollution (due to the extent of asphalt in Auto Cities); and the economic problems due to the high costs of sprawl-related infrastructure, direct transportation costs; and indirect transportation costs (road accidents, pollution, etc.); along with the transportation related loss of the public realm, safety and community. It is not possible to solve sustainability in cities without first addressing automobile dependence (Newman \& Kenworthy, 1999).

\subsection{Causes of Dependency on Automobile}

Factors that cause and contribute to automobile dependency are many and can be direct, indirect or complex factors. Many researchers have highlighted several diverse reasons for automobile dependence. Litman \& Laube (2002), assert that automobile dependency does not stand alone, it also influences another sector including transportation and land use factors. Decreasing number of people using alternative modes may occur by inconvenience in facilities. Similarly, Stage (2009) reported that when people live far away from their workplace and prefer driving, car dependence ensues. Subsequently, Mackett (2002) noticed that the consequence of car dependence is not only the use of the vehicle, but also a belief that the activity or function will not be fully and proper done if they do not use automobile. Car dependency occurs because of dynamic situation that happens eventually aligned with their personal situation (Goodwin, 1997). Below is a diagram to illustrate the cycle of automobile dependency in cities. 


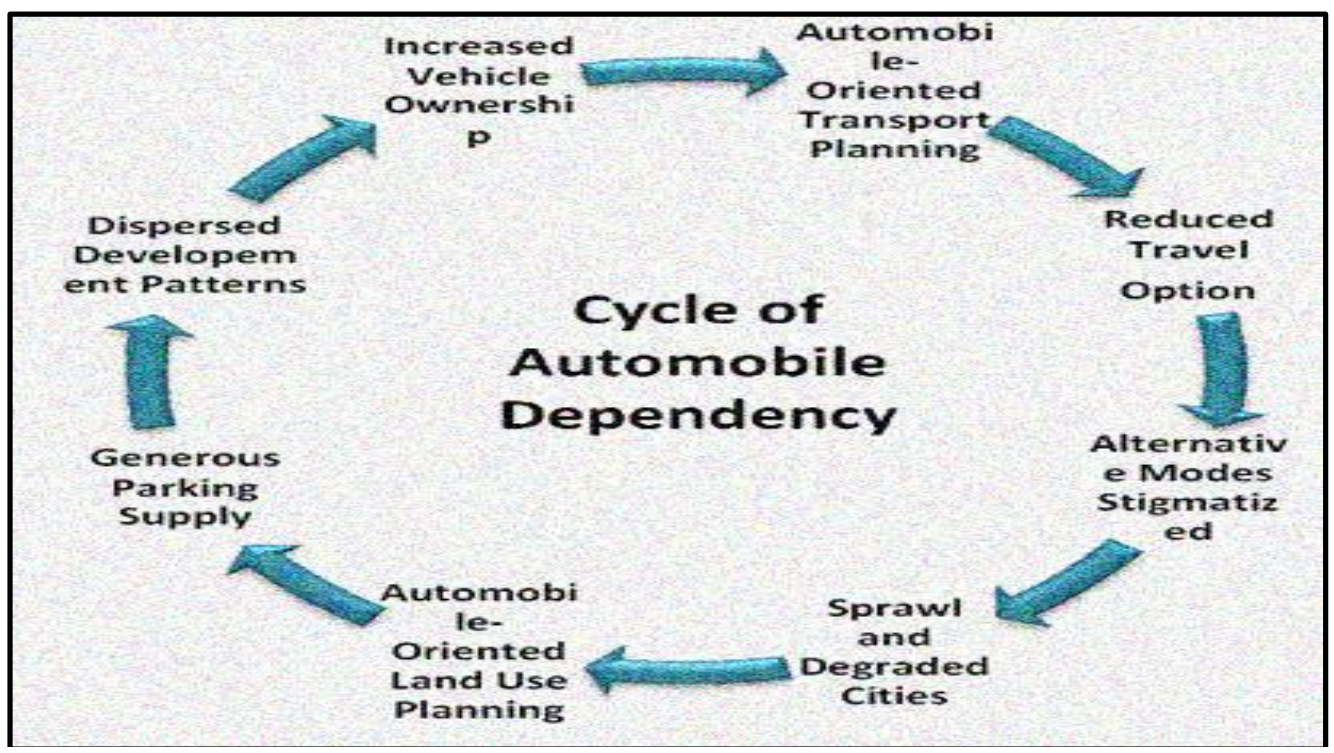

Figure 1; Cycle of Automobile Dependency

Source; Victoria Transport Policy institute

From figure 1 above, each factor fuels car dependency and it is in a viscous circle of continual growth of the menace. Increased vehicle ownership as a show of affluence of the city in quest of travel convenience and time saving, results to automobile oriented transport planning to a reduced travel option down to stigmatization of alternative modes of mobility, suburbanization and degraded cities. In view to remedy the situation, this leads to automobile oriented land use planning, further to generous parking supply resulting into dispersed development patterns and invariably back to the increased car ownership. These causes continue to flow in a sequential manner reinforcing each other and adding to the problem.

\subsection{Indicators of Automobile Dependency}

Litman, (2011) developed some criteria to classify automobile dependent cities. His classification was based on land use pattern, the transportation system, the behavioural attitude of population, vehicle ownership etc. and rated cities as low, medium and highly automobile dependent. See table below with its variables 
Table 1: Attributes of automobile dependency.

\begin{tabular}{|c|c|c|c|c|}
\hline INDICATOR & DESCRIPTION & LOW & MEDIUM & HIGH \\
\hline Name & $\begin{array}{c}\text { What they are } \\
\text { generally called by } \\
\text { planners }\end{array}$ & $\begin{array}{c}\text { Low car } \\
\text { dependency }\end{array}$ & Multi-modal & $\begin{array}{l}\text { Automobile } \\
\text { Dependent }\end{array}$ \\
\hline Vehicle Ownership & $\begin{array}{c}\text { Per capita motor vehicle } \\
\text { ownership (usually measured } \\
\text { per } 1000 \text { population) }\end{array}$ & $\begin{array}{l}\text { Less than } 200 \text { per } \\
1000 \text { pop. }\end{array}$ & $200-400$ & $400+$ \\
\hline Vehicle Travel & $\begin{array}{l}\text { Per capita annual motor vehicle } \\
\text { mileage }\end{array}$ & $\begin{array}{l}\text { Less than } 6000 \\
\text { km }\end{array}$ & $6000-12000 \mathrm{~km}$ & $12000 \mathrm{~km}$ plus \\
\hline Vehicle Trips & $\begin{array}{c}\text { Automobile trips as a portion } \\
\text { of total personal trips }\end{array}$ & Less than $50 \%$ & $50-80 \%$ & $80 \%+$ \\
\hline $\begin{array}{c}\text { Quality of } \\
\text { Transport } \\
\text { Alternatives }\end{array}$ & $\begin{array}{l}\text { Convenience, speed, comfort, } \\
\text { affordability and prestige of } \\
\text { walking, cycling and public } \\
\text { transit relative to driving }\end{array}$ & $\begin{array}{c}\text { Alternative modes } \\
\text { are of competitive } \\
\text { quality }\end{array}$ & $\begin{array}{l}\text { Alternative modes } \\
\text { are somewhat } \\
\text { inferior }\end{array}$ & $\begin{array}{l}\text { Alternative modes } \\
\text { are very inferior }\end{array}$ \\
\hline $\begin{array}{l}\text { Relative Mobility of } \\
\text { Non-Drivers }\end{array}$ & $\begin{array}{c}\text { Mobility of personal travel by } \\
\text { non-drivers compared with } \\
\text { drivers }\end{array}$ & $\begin{array}{l}\text { Non-drivers are } \\
\text { not severely } \\
\text { disadvantaged }\end{array}$ & $\begin{array}{l}\text { Non-drivers are } \\
\text { moderately } \\
\text { disadvantaged }\end{array}$ & $\begin{array}{l}\text { Non-drivers are } \\
\text { severely } \\
\text { disadvantaged }\end{array}$ \\
\hline Land use patterns & $\begin{array}{c}\text { Land use density (residents and } \\
\text { jobs per acre) and mix } \\
\text { (proximity of different land use } \\
\text { types) }\end{array}$ & $\begin{array}{l}\text { Very compact and } \\
\text { mixed }\end{array}$ & $\begin{array}{l}\text { Moderately compact } \\
\text { and mixed }\end{array}$ & $\begin{array}{l}\text { Dispersed and } \\
\text { homogenous }\end{array}$ \\
\hline Transport system & $\begin{array}{c}\text { Type of transport facilities and } \\
\text { services available }\end{array}$ & $\begin{array}{l}\text { Mainly non- } \\
\text { motorized and } \\
\text { public transit }\end{array}$ & $\begin{array}{l}\text { Very mixed non- } \\
\text { motorized, public } \\
\text { transit and } \\
\text { automobile }\end{array}$ & $\begin{array}{l}\text { Mainly automobile } \\
\text { (roads and parking } \\
\text { facilities) }\end{array}$ \\
\hline Roadway design & Design features of public roads & $\begin{array}{l}\text { Highly pedestrian } \\
\text { oriented }\end{array}$ & Mixed & $\begin{array}{l}\text { Designed to } \\
\text { maximize auto } \\
\text { traffic speeds and } \\
\text { volumes }\end{array}$ \\
\hline Shopping Options & $\begin{array}{l}\text { Where retail and other public } \\
\text { services are located }\end{array}$ & $\begin{array}{l}\text { Along public } \\
\text { streets }\end{array}$ & $\begin{array}{l}\text { Mainly along public } \\
\text { streets near transit } \\
\text { areas }\end{array}$ & $\begin{array}{l}\text { In private malls, } \\
\text { located along } \\
\text { major highways }\end{array}$ \\
\hline $\begin{array}{l}\text { Market Distortions } \\
\text { Favouring } \\
\text { Automobile Use }\end{array}$ & $\begin{array}{l}\text { Relative advantage provided to } \\
\text { automobile transport over } \\
\text { other modes in planning, } \\
\text { funding, tax policy, etc. }\end{array}$ & $\begin{array}{l}\text { Minimal bias } \\
\text { favouring } \\
\text { automobile travel }\end{array}$ & $\begin{array}{l}\text { Moderate bias } \\
\text { favouring } \\
\text { automobile travel }\end{array}$ & $\begin{array}{l}\text { Significant bias } \\
\text { favouring } \\
\text { automobile travel }\end{array}$ \\
\hline $\begin{array}{c}\text { Automobile } \\
\text { commute mode } \\
\text { split }\end{array}$ & $\begin{array}{l}\text { How people travel to work and } \\
\text { school }\end{array}$ & Less than $35 \%$ & $35-65 \%$ & More than $65 \%$ \\
\hline Errand travel & $\begin{array}{l}\text { How people normally travel to } \\
\text { stores, professional } \\
\text { appointments, recreation } \\
\text { activities, etc. }\end{array}$ & $\begin{array}{l}\text { Mostly walking, } \\
\text { cycling and public } \\
\text { transit }\end{array}$ & $\begin{array}{l}\text { Walking, cycling, } \\
\text { public transit and } \\
\text { automobile }\end{array}$ & Mostly automobile \\
\hline $\begin{array}{l}\text { Performance } \\
\text { Indicators }\end{array}$ & $\begin{array}{l}\text { How transport system } \\
\text { performance is evaluated }\end{array}$ & $\begin{array}{l}\text { Quality of walking, } \\
\text { cycling and public } \\
\text { transit }\end{array}$ & Multi-modal & $\begin{array}{l}\text { Automobile- } \\
\text { oriented }\end{array}$ \\
\hline
\end{tabular}

Source; Litman, 2011 


\subsection{Policy decision impacts}

Cities of third world nations are at a crossroad. The mobility policies they adopt determines their transportation alternatives and land use growth patterns, which in turn will influence travel patterns and will have different financial, social and environmental effects, as demonstrated in Figure 2. Many present strategies are likely to produce cardependent transportation systems that tend to raise future expenses and hazards.

\section{Policy Decision}

(infrastructure investment, roadway design, fuel taxes, parking fees, zoning codes, etc.)

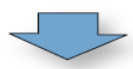

Transport Options

(quality of walking, cycling, transit, driving, etc.)

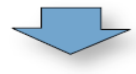

Travel Activity

(the amount of walking, cycling, public transit, automobile travel, etc.)

Economic, Social and Environmental Impacts

(congestion, accidents, vehicle costs, fuel consumption, pollution emissions, etc.)
Land Use Development Patterns

(location of homes, services, jobs, etc.)

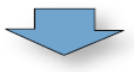

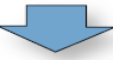

Figure 2; Policy decision impacts

Source; Litman, 2011

To a large extent, automobile dependence results from public policy and planning choices which support car travel and sprawl to the detriment of other modes of transport and more sustainable land use. For instance, most Nigerian cities have minimum parking standards in zoning regulation. These requirements contribute to car dependence by encouraging and increasing the convenience of driving. It invariably creates a self-reinforcing sequence as illustrated in Figure 1, where one Policy decision impacts negatively on the other to support automobile dependency.

\section{Study Area}

Enugu is a medium- sized city in the south-eastern region of Nigeria with geographic coordinates $6^{\circ} 30^{\prime} \mathrm{N} 7^{\circ} 30^{\prime} \mathrm{E}$. It has a population of over 722,664 and a density of $3,400 / \mathrm{sq} \mathrm{mi}\left(1,300 / \mathrm{km}^{2}\right)$ and ranks 9 th most populous city according to the 2006 Nigerian population Census (Okeke, etal 2020). It is home of the Igbo of south-eastern Nigeria and doubles as the capital city, of Enugu State (top of the hill). Considered the oldest urban area in Southeast Nigeria's Igbo-speaking region, the city owes its historical importance to the British geologists' discovery of coal in 1909. It has an area coverage of 215 sq. $\mathrm{mi}\left(556 \mathrm{~km}^{2}\right)$ and falls within the Tropical Savanna Climate. 


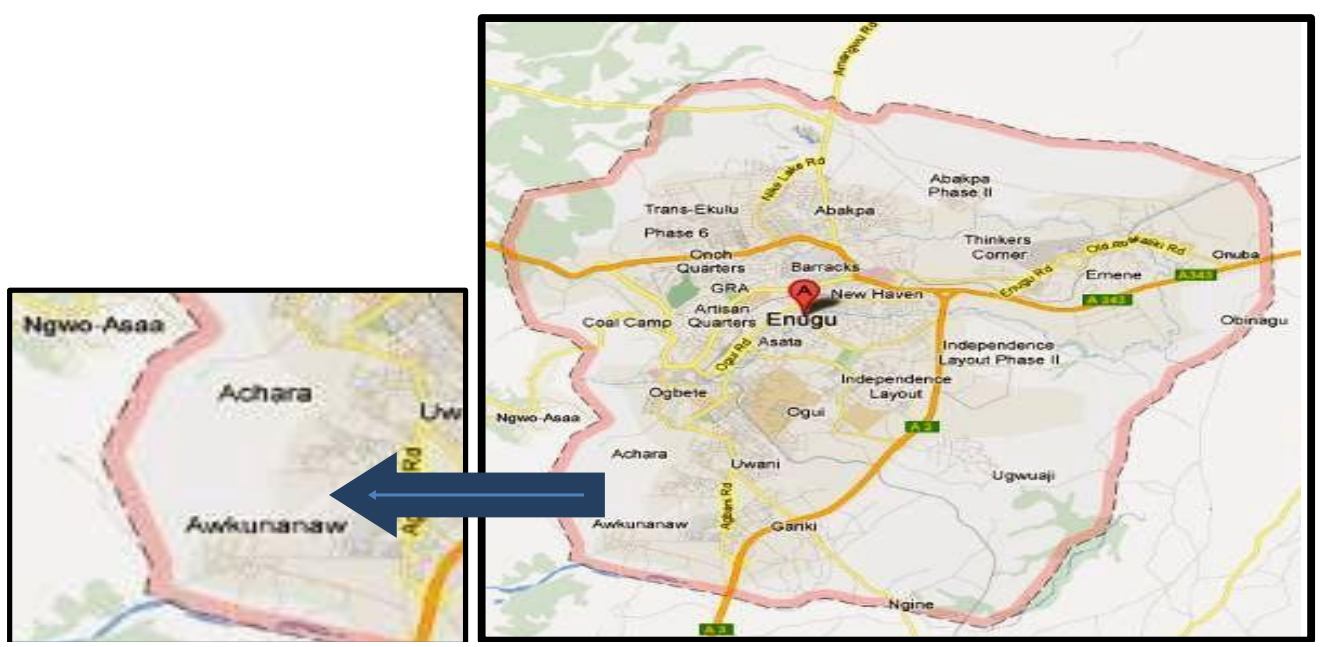

Figure 3; Map of Enugu showing Achara Layout

Source; Google Earth 2019

Achara Layout is located in Enugu South LGA of Enugu State. Enugu South LGA has an area of about $106 \mathrm{~km}^{2}$ and a population of about 244,852 at the 2006 census. Achara Layout is one of the areas of Enugu that was mapped out in the 1960s for residential development and now it has grown from a residential suburb to a major commercial area especially along Agbani Road, the main high street. Its streets are heavily built up with storeys of block of flat development and population of 72,894 according to the 2006 Nigerian population Census and projected estimate of 102,761 people in 2019. It has a grid patterned road and street network and can be assessed from all parts of Enugu. The area is densely populated because it serves as habitat for many working class citizens of Enugu.

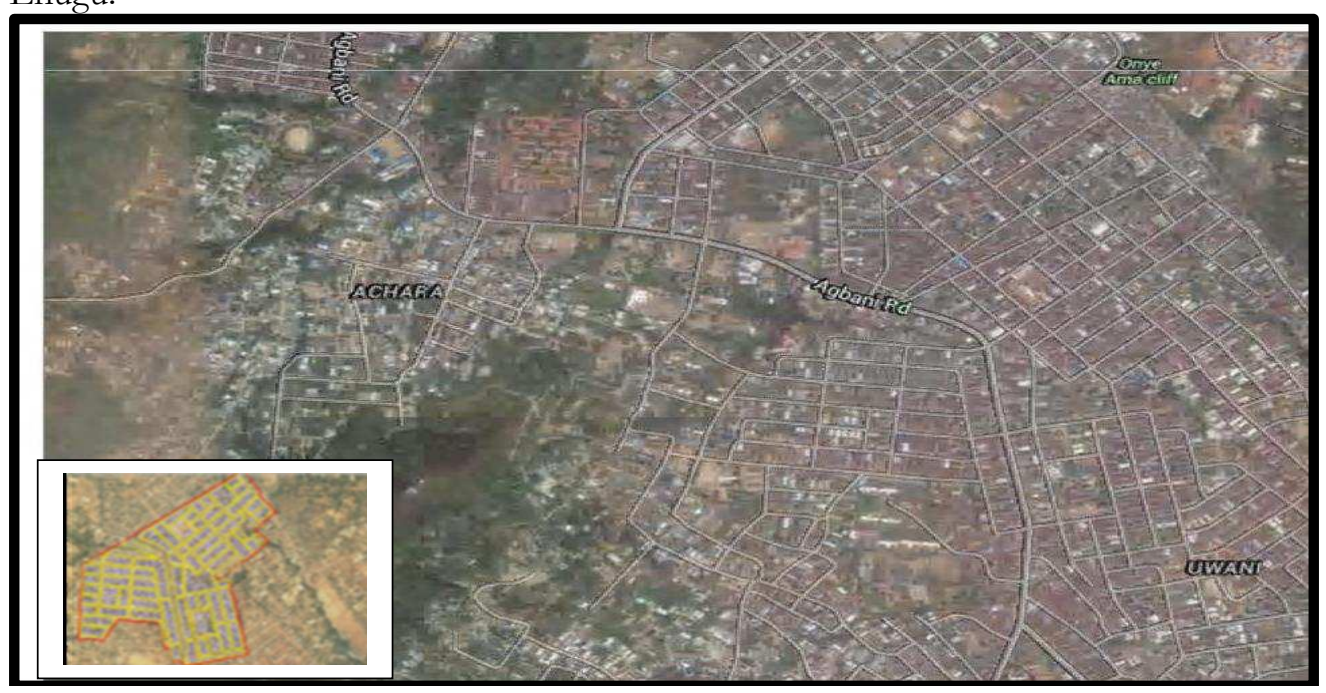

Figure 4; satellite Image of Achara Layout

Source; Google map 


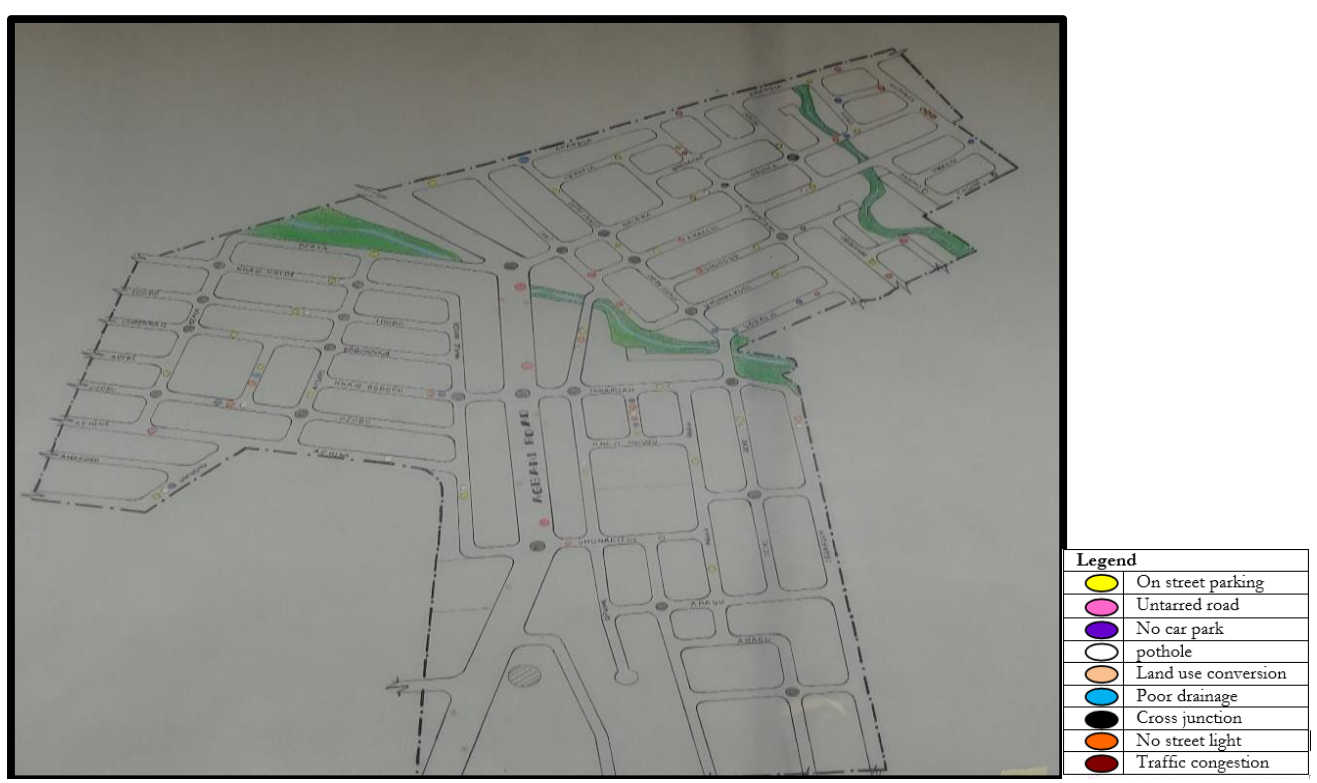

Figure 5; Map of Achara Layout

Source; Researcher's field work.

\subsection{Research Methodology}

A descriptive survey research design was adopted with a combination of both primary and secondary sources of data employed for the study. Using a simple random sampling method, Achara Layout in Enugu was considered for the study being a zone for residential function accessible from many parts of the city and have survived subsequent administration from colonial period to present age, housing a fairly large percentage of Enugu populace and heavily built-up. The instrument for data collection was a field survey by the researchers taking photographs as evidence for the study. A half day $(7 \mathrm{am}$ to $7 \mathrm{pm}$ ) count of automobile or traffic census was conducted during day time hours to determine the traffic flow and volume of automobile in the residence. The result was compared to the criteria developed by Litman, (2011) of automobile dependent cities. Further analysis were made by inferential means drawing out conclusions and deduction from the study based on the researcher's opinion. The secondary sources of data include the internet, relevant books, journals, conference reports and statistics obtained from 2006 Nigeria Population Census Result for Enugu State.

\section{Findings}

The result of traffic count is presented below in table 2 with the different types of automobile found within the Layout. Also noted are the peak hour traffic and volume. 
Table 2; Traffic census of Achara Layout

\begin{tabular}{|c|c|c|c|c|c|c|c|c|c|}
\hline \multicolumn{10}{|c|}{ AGBANI ROAD (MAYOR) } \\
\hline \multicolumn{10}{|c|}{ PERIOD OF TRAFFIC CENSUS FROM 7:00am-7:00pm } \\
\hline Period & $\begin{array}{l}\text { Private } \\
\text { Cars }\end{array}$ & $\begin{array}{l}\text { Public } \\
\text { Cars }\end{array}$ & $\begin{array}{l}\text { Comm. } \\
\text { Public } \\
\text { Bus }\end{array}$ & $\begin{array}{l}\text { Private } \\
\text { Bus }\end{array}$ & $\begin{array}{l}\text { Tipper } \\
\text { /Lorries }\end{array}$ & $\begin{array}{l}\text { Trailer } \\
\text { Vehicle }\end{array}$ & Tricycles & $\begin{array}{l}\text { Motor- } \\
\text { cycles }\end{array}$ & Total \\
\hline 7:00-8:00am & 252 & 68 & 592 & 23 & 15 & 3 & 480 & 2 & 1445 \\
\hline 8:00-9:00am & 468 & 127 & 766 & 30 & 25 & 4 & 960 & 1 & 2371 \\
\hline 9:00-10:00am & 462 & 134 & 617 & 27 & 31 & 4 & 1085 & - & 2360 \\
\hline 10:00-11:00am & 565 & 74 & 544 & 31 & 27 & 1 & 825 & - & 2067 \\
\hline 11:00-12:00pm & 630 & 78 & 554 & 43 & 36 & 3 & 899 & - & 2241 \\
\hline 12:00-1:00pm & 406 & 70 & 493 & 26 & 33 & 4 & 654 & - & 1686 \\
\hline 1:00-2:00pm & 385 & 48 & 498 & 21 & 14 & 2 & 618 & - & 1586 \\
\hline 2:00-3:00pm & 391 & 103 & 564 & 37 & 27 & 4 & 665 & 1 & 1792 \\
\hline $3: 00-4: 00 \mathrm{pm}$ & 477 & 171 & 673 & 15 & 16 & 2 & 637 & 1 & 1892 \\
\hline 4:00-5:00pm & 340 & 77 & 632 & 33 & 17 & 6 & 527 & 4 & 1636 \\
\hline 5:00-6:00pm & 292 & 69 & 559 & 25 & 16 & 2 & 662 & 1 & 1666 \\
\hline 6:00-7:00pm & 249 & 70 & 530 & 18 & 10 & 2 & 557 & - & 1436 \\
\hline $\begin{array}{l}\text { TOTAL } \\
\text { VOLUME }\end{array}$ & 4927 & 969 & 7050 & 329 & 267 & 37 & 8569 & 10 & 22178 \\
\hline \multicolumn{4}{|c|}{ LEGEND } & & & & & & \\
\hline \multicolumn{4}{|c|}{ Volume with peak vehicle } & & & & & & \\
\hline & \multicolumn{3}{|c|}{ Peak hour traffic } & & & & & & \\
\hline & \multicolumn{3}{|c|}{ Total traffic volume } & & & & & & \\
\hline & \multicolumn{3}{|c|}{ Vehicular peak period } & & & & & & \\
\hline
\end{tabular}

Source; Researcher's field work (2019)

From table 2, the total volume of vehicle is 22,178 and tricycle has the highest total traffic volume of 8,569. Motorcycle has the lowest traffic count of 10 because the State Government banned its use on the road in 2012 due to its frequent association with criminal activities in the State capital. The peak hour traffic is between 8am - 9am because of movement of workers and school children to offices and classes respectively. 
Although peak hours for different automobile types vary significantly but commercial vehicle still maintain morning hours of $8 \mathrm{am}-10 \mathrm{am}$ as peak hour period emphasizing that more movement to school and place of work occurs then.

The result of 1991 Population census community harmonized with 2006 Local Government Area census result for Enugu state with projections.

Table 3; 2006 Population census Result for Enugu South LGA State

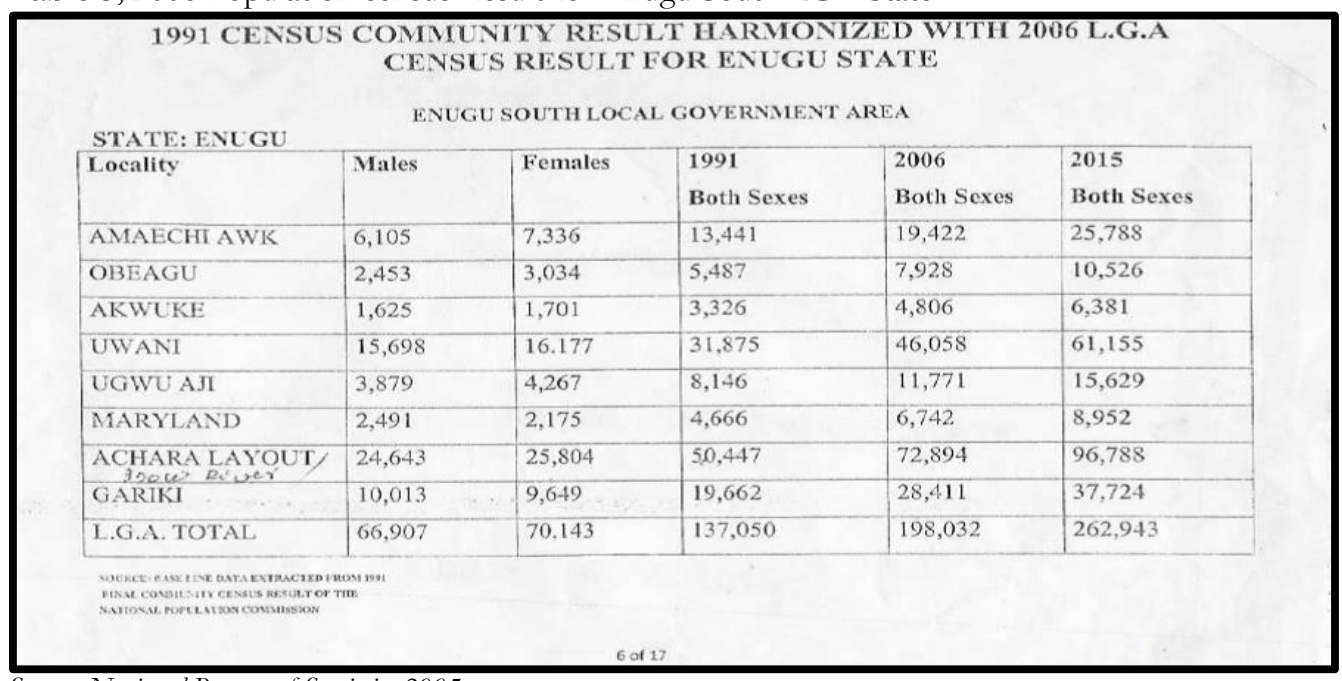

Source; National Burean of Statistics 2005.

Statistics from population census conducted in Nigeria shows that there is an incremental growth of study area population from 50,447 in 1991 to 72,894 in 2006 to 96,788 in 2015 and projected 102,671 in 2019

\section{Discussion}

\subsection{Impact of Automobiles in the Life of City Dwellers}

The advent of automobile has improved standard of living and comfortability, in as much as it came with good purpose from the onset, with passage of time, its negative impact is becoming an issue to be resolved in cities. The negative impact of automobile on the life of city include;

\section{a) Traffic and Congestion}

Traffic congestion in Achara Layout caused by automobile has been longstanding and persistent. Traffic volume of 22,178 automobile obtained from the survey to service 102,671 people is comparatively high, showing that one out of every four persons in the area owns or has a car. Comparing with Litman, (2011) first criteria for automobile dependent city, Per capita ownership of motor vehicles (generally estimated per 1000 population) is above 400 and therefore considered high. The typical grid layout of urban road network adopted intensifies the stream of circulation pressure on the collector roads, as there are tendencies of the street and lane to converge traffic to the core and exit of the layout. Among residents, traffic has become a popular point of discussion in the streets as more cars travel to and fro home and work. In many cases, private car 
owners blame commercial automobile drivers for the traffic problems experienced in study area.

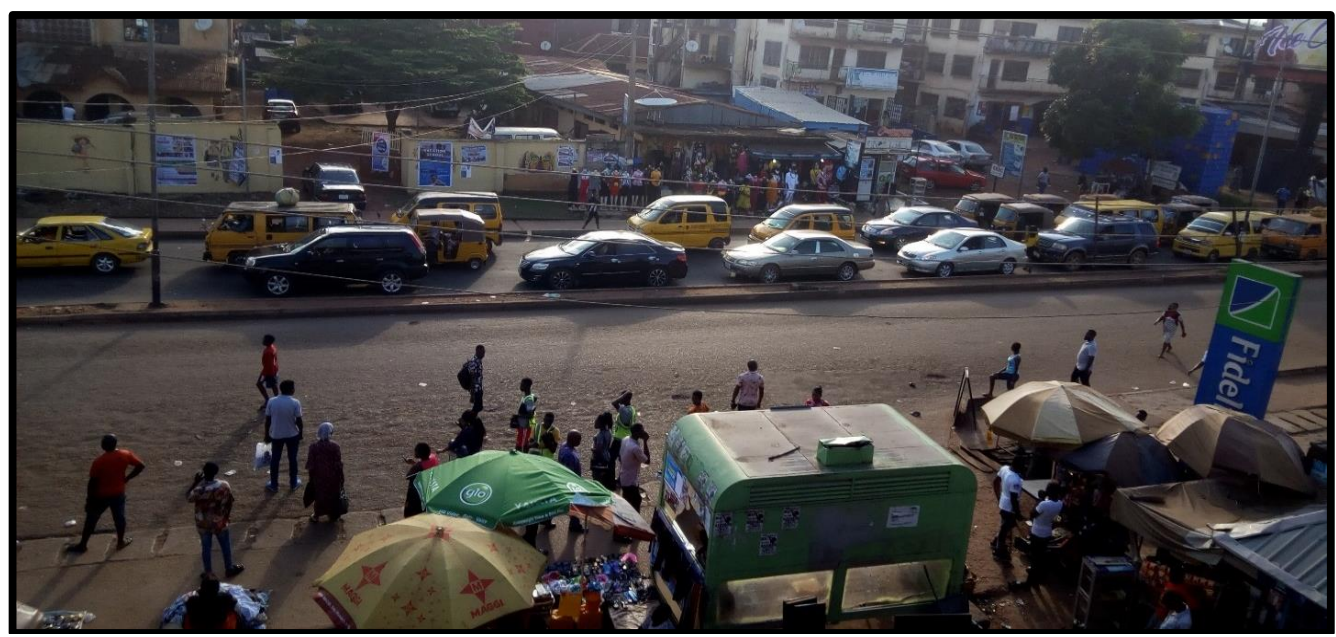

Figure 6; shows traffic congestion in Mayor Achara Layout

Source; Researcher's field work, 2019

Viewed as the principal urban transportation problem in recent time in Mayor, Amechi, Amuokwe, Gariki and Ogbete market areas, traffic bottleneck has appeared to be the foremost justification for road expansion in Enugu urban. Given the ongoing development and continual expansion of the network of roads, the most striking physical impact of increasing motor vehicles in Achara Layout Enugu is traffic congestion. Planners are often unaware of the fact that the development of urban motorways to increase traffic speeds and decrease congestion will promote increased use of automobile. Automobiles did not invent traffic jams. Martin (2010), noted that "as a technology motor vehicle did not generate contemporary traffic issues more than the use of horses in cities of the nineteenth century. However, the problem is the overuse of the automobile coupled with its gross accommodation of social space as a homogeneous mobility system. Traffic congestion result to both excessive consumption of energy and loss of economic productivity.

\section{b) Automobile Parking}

Cars even at rest or not moving creates problem in the metropolis. It is sardonic, that a system developed to offer better flexibility for individuals to fulfill their mobility needs remains largely fallow much of its lifetime. Even a functional road transits structure that allows complete free movement of automobile will still not address mobility issue, because the target of every automobile is a stop at desired terminal or destination. For example, an average motor vehicle is in motion roughly $500 \mathrm{hrs}$ per-annum and is parked for the remaining 8,260 hrs. (Martin, 2010). Consider the fact that for about 90 percent of its lifespan the average automobile is parked and unused, and that even when used, it is almost empty. This only explain that it is an inefficient means of transportation. Along the busy street of Achara Layout are off side double lane parking leaving only one narrow passage in the middle for the moving vehicle. See figure 7 below. 


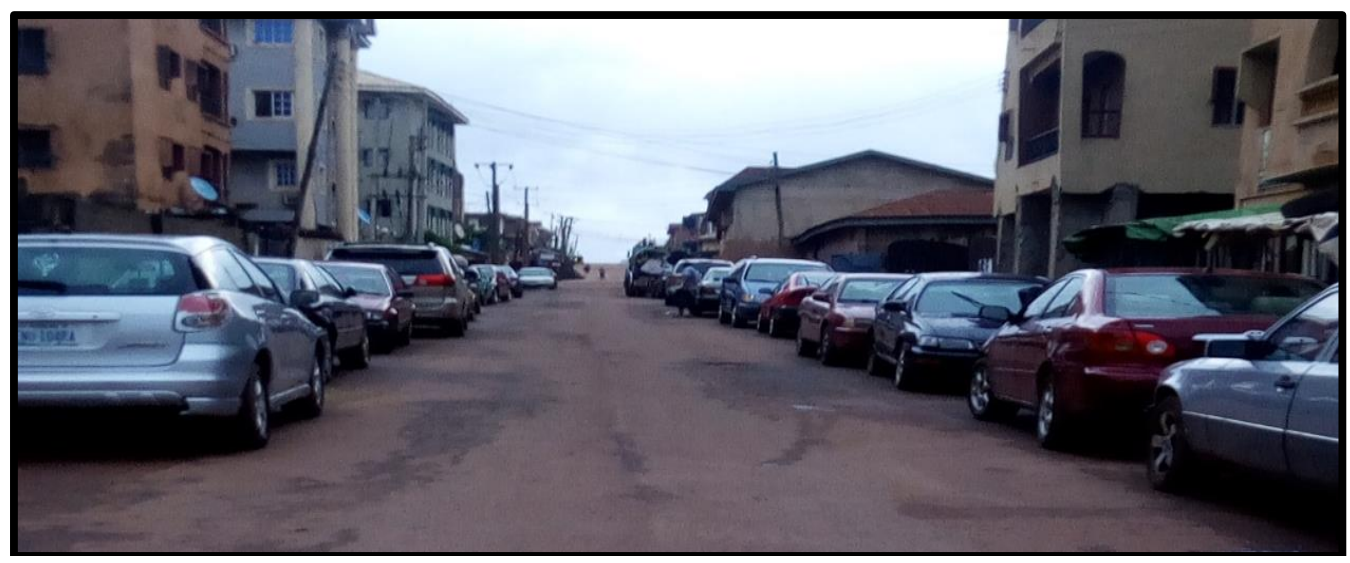

Figure 7; shows double side off street parking along Igbariam Street Achara Layout

Source; Researcher's field work, 2019

Also consider the substantial space needed to hold vehicles in parking mode. With the standard design requirement of two automobile for every household, each motor vehicle in the layout would require two $23 \mathrm{~m}^{2}$ off-street parking lots (neither one in a garage). It implies that $0.2 \mathrm{~km}^{2}$ of space would be a necessity for parking alone for every 10,000 households, adding 15 to 25 percent to urban street space requirements. Parking spaces are relatively unproductive land use and their excessive existence leads to unnecessary stress on land with greater financial potential.

\section{c) Traffic Control}

Congestion problems led not only to plans for road expansion in the study area, but also to the introduction of human and mechanical traffic control as seen in figure 8 below. Not less than 18 traffic wardens are posted to the very busy Amechi, Mayor and Amuokwe junction daily within the layout and it seems not enough to tackle the traffic crisis.

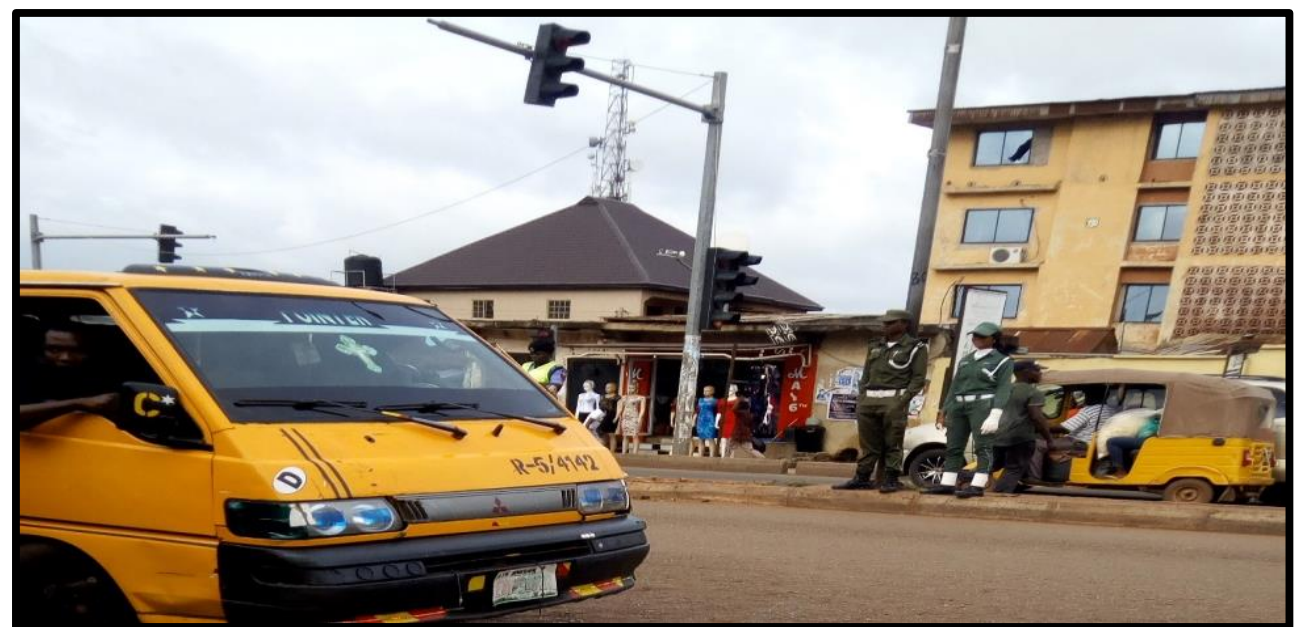

Figure 8; shows traffic control mechanism in mayor, Achara Layout

Source; Researcher's field work, 2019 
As a visual reminder of the need to properly separate foot-travelers from moving cars (and automobile from automobile), traffic lights and symbols have become an indelible part of city's urban infrastructure alongside traffic wardens and road markings. Even with the existing different traffic control mechanism, street safety is chronically threatened as there is less provision for sidewalk along the street. Accidents often occur as many people are injured in auto crash. According to World Health Organization (2013), automobile related accidents ranks highest among causes of death in urban centres. There are 1.25 million road traffic deaths globally with millions more sustaining serious injuries and living with long-term adverse health consequences. While safety is expected to improve with the introduction of measures like use of seat belts and airbags, speed reducing bumps, and narrowness of streets, neither have they worked very effectively as adjusting to new signs proved difficult for motorist used to having their own way on the streets, and many others simply repelled their introduction or violated it. As observed by Clay (1999), traffic lights, road markings and symbols do not only express a new physical presence in urban environments, but also impose[d] a powerful social influence and control over the most basic human behaviour of whether to move or stop.

\section{d) Automobile services stations}

The earmark of over dependency on automobile in Achara layout, Enugu is not limited to the cars and parking bays, streets and roads, traffic lights and symbols. But just like horses that need fodder and stables, train that require coal and stations; cars too need lubricant, petrol, diesel, repair kits and garages. Very crucial, they need fuel and service stations. Automobiles strongly depend on petroleum products, which is usually imported, and this will make cities exposed to energy crises in the wake of future oil depletion. As the sale of automobile skyrockets, the high demand for petroleum products resulted in a more organized manner of delivering it. Initially, a driver went to one location for diesel or gasoline, and another place for washing, lubrication, maintenances, pneumatics and other accessories. But the combination of these activities is actually more convenient for users and has caused the spring up of new marketing opportunities for entrepreneurs to harness the advantage of automotive boom. Not less than 5 petrol stations are located within Achara layout and most of these filling station in the area serve as bus stops or bay. Other facilities related to the automobile, for example workshops, drive-through shops, car wash, or auto laundry and many other "drive-in" establishments, are rapidly surfacing, suggesting the degree to which cars have entered the city not as a toy for the elite, but as an essential resource for mobility.

\section{e) Automobiles and Sprawl}

Research has it that, urban sprawl is the root of many environmental problems. The motor vehicle has a rapacious hunger for land and this form of urban development disperses people, businesses, and scatter workshops over a broad landscape with substantial patches of vacant or fallow land spread through stretches of houses and commercial strips along roads. Below is the cityscape of Mayor Junction in Achara layout and the dense population of human and automobiles. 


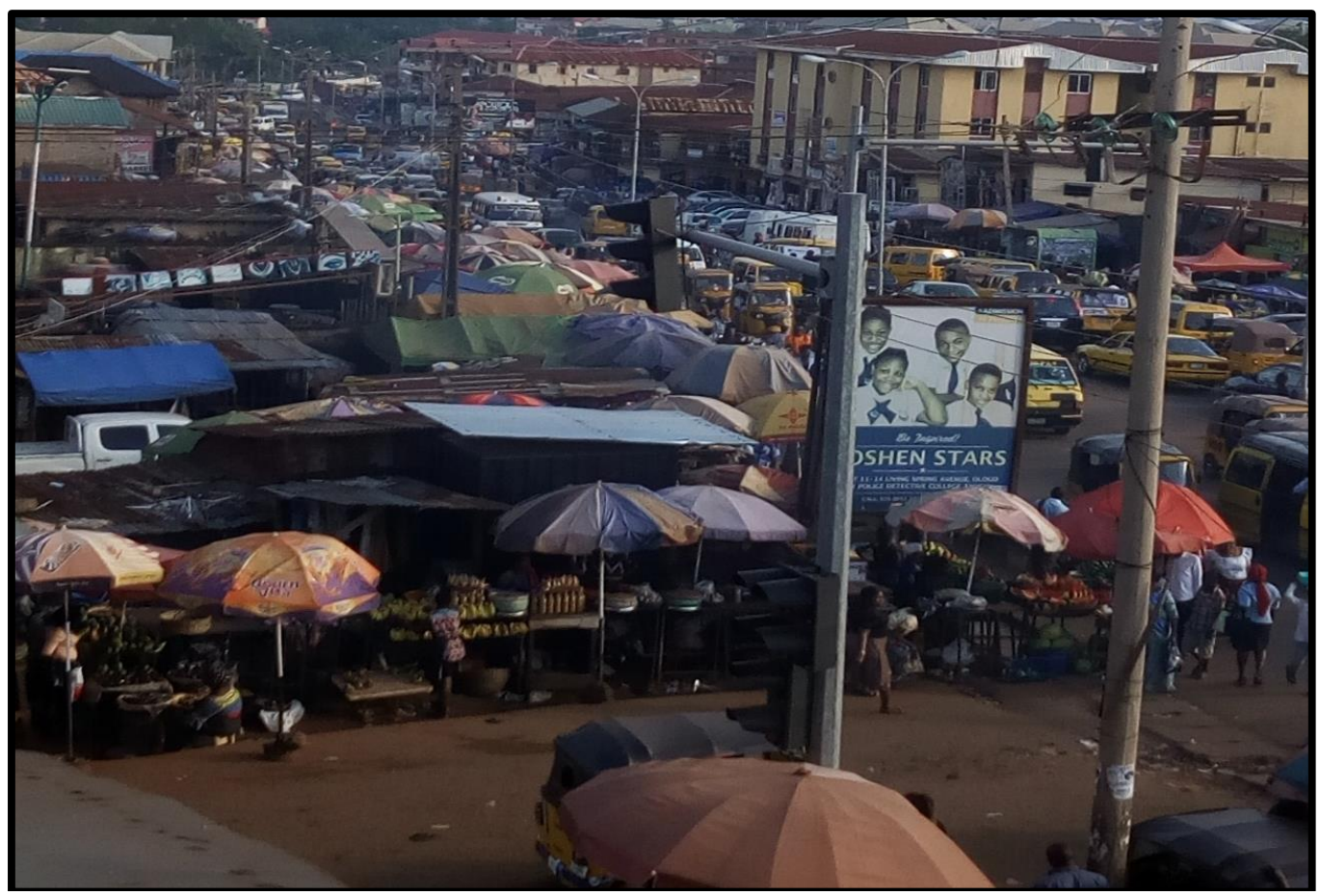

Figure 9; shows urban sprawl tendency in Achara Layout

Source; Researcher's field work, 2019

Automobile is both a force of cohesion and diffusion, which has helped to change suburbanization scale and form. It is an enabling technology that permits greater dispersion of people. As seen from the result of the previous censuses conducted in Nigeria, there is an incremental growth of Achara layout population from 50,447 in 1991 to 72,894 in 2006 to 96,788 in 2015 and projected 102,671 in 2019, without a corresponding growth in social amenities to match up the current housing and transport demands. Motor vehicles scatter the population arbitrarily; roadways and streets turn out to be the basic common link between individuals, their workplaces and homes. According to Okeke et al (2020) the colonial city of Enugu is gradually drifting with signs of urban fragility and consequently is currently faced with enormous challenges in terms of infrastructure provision and the need to cope with the increasing demand of transport.

\section{f) Businesses on Roadside}

New roadside businesses came with freeways, which have also changed Achara's physical, cultural and economic landscape. (See figure 10 below) Outdoor advertising, especially billboards that were formally an overt form of product advertising flooded the roads and even took to the streets helping to market products and promoting services. The significant proportion and garishness of billboards, together with mushrooming roadside businesses along and adjacent to deteriorated residential properties, stirred attempts to embellish roadside. Furthermore, the automobile has not only lend a hand to arouse a novel type of landscape but also inspired a commercial urban-architectural 
movement. With the increase dependency on automobile and subsequent rise in demand for vehicles, a marriage of architecture and ads has been prompted birthing a fusion of building and sign. Every storey building along Agbani road in the Layout is used as an advertisement space as Organizations or individuals subscribe to Landlords to put up a notice for the public because it can be easily seen and read by road users.

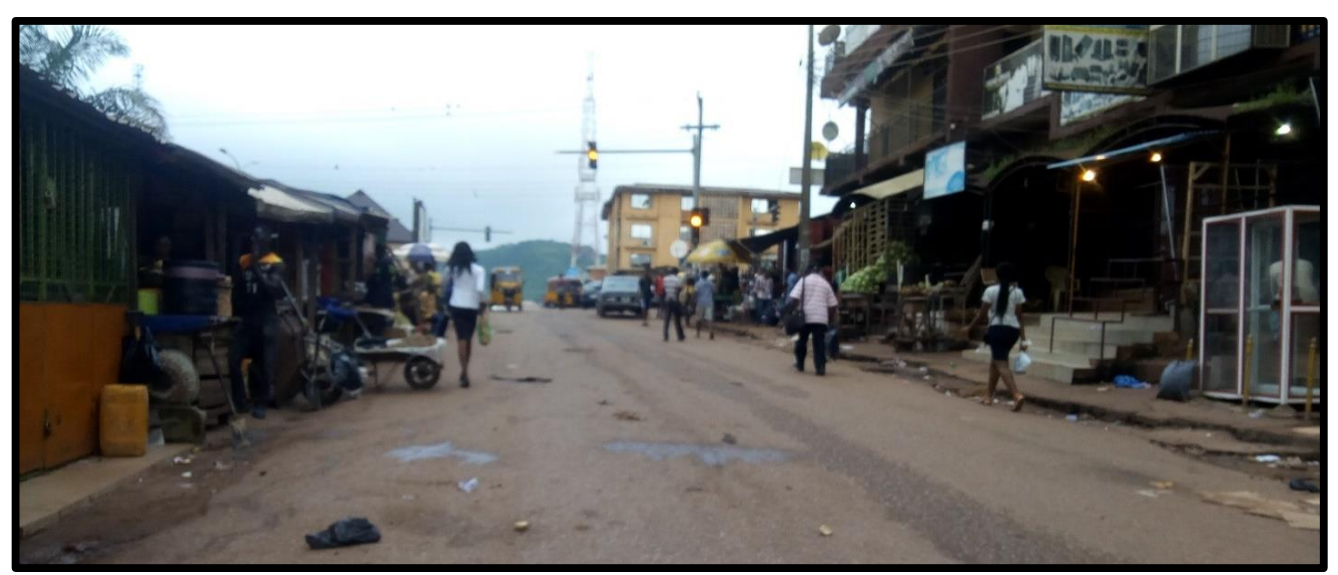

Figure 10; shows road side business and bill boards in Achara Layout

Source; Researcher's field work, 2019

Due to the large number of people the layout receives and converge in traffic gridlock, trading and roadside businesses have become a common feature of its roads and streets as goods and wares are displayed on tables, hangers, wheel barrows and hawkers are seen moving to and fro selling their goods. On the other hand, business activities along the road is a means of sustenance for urban poor who cannot afford to own or rent a shop. Many conclude it is more lucrative than staying in lockup stores.

\section{g) Environment}

The environment is at the receiving end of the ill effect of automobile in the area. A total of 22,178 vehicles contribute its quota to environmental disturbance in the area. See graph below. 


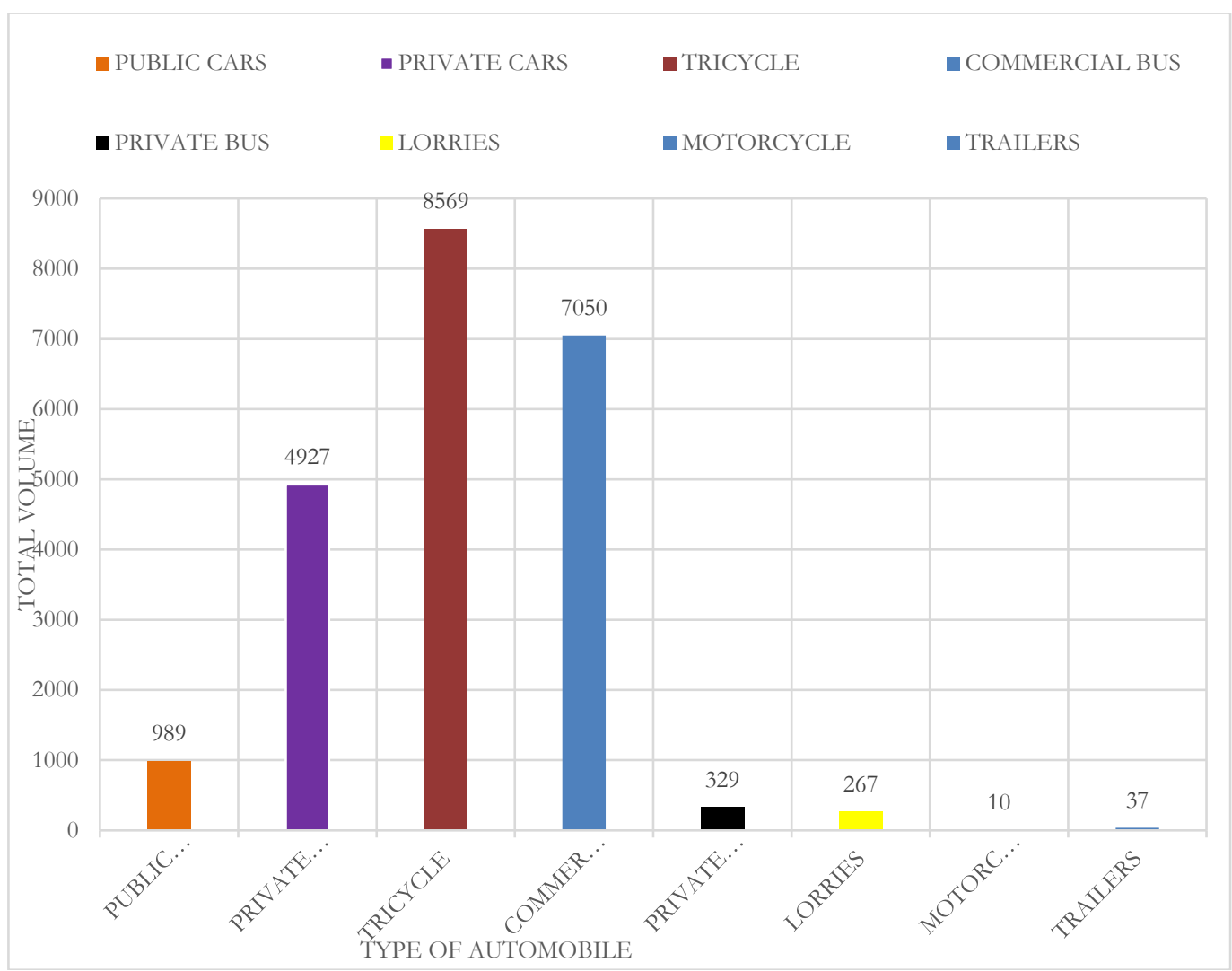

Figure 11; Graph of automobile dependency in Achara Layout

Source; Researcher's field work, 2019

From the graph of traffic census by vehicle volume, tricycle and commercial buses sum up to 15,619 automobiles constantly navigating the roads and streets causing the following environmental hazard.

- Noise pollution: - Traffic on the road is main source of noise in the layout. The intensity of noise pollution from automobile varies with the size, the speed of travel, tyre design, frequency of travel, vehicle maintenance levels etc.

- Use of Resources: - The manufacture, operation and maintenance of vehicles impact the environment by using non-renewable resources such as: Metals, Petroleum, fossil fuels etc.

- Water Quality: -automobile usage has an indirect effect on water quality because oil and particles get washed into drains and subsequently to creeks and rivers. Fumed filled air from automobile mixes with rainwater and affect its quality.

- Greenhouse gases: - Automobiles make use of carbon-based fuels which produce greenhouse gases that contribute to global warming and climate change as seen from figure 12 below. 


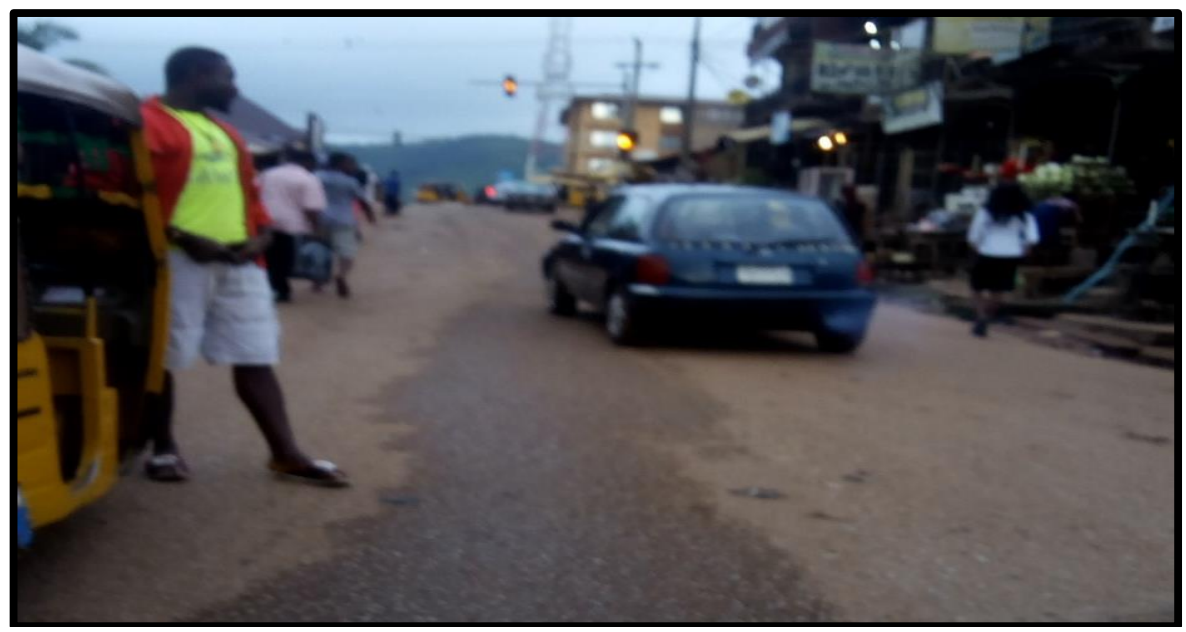

Figure 12; shows environmental pollution of noise, air and water in Achara Layout

Source; Researcher's field work, 2019

The main greenhouse gas is carbon dioxide. Others include nitrous oxide and methane. Reducing fuel consumption will reduce these emissions. Research has it that $2.3 \mathrm{~kg}$ of carbon dioxide is emitted into the atmosphere for each litre of petrol used. Now the average passenger vehicle emits about 4 tonnes of carbon dioxide each year. Therefore, multiplying the total vehicle count of 22,178 by 4 tonnes, the result is 88,712 tonnes of carbon dioxide. This is the quantity of carbon dioxide, emanating from Achara layout annually, and thus the figure is relatively high for a residential area.

- Air Quality: - Air pollution is a common phenomenon at Mayor bus stop, Achara layout. This has negative health effects, especially for vulnerable people and the elderly. Air pollution is not uniform across the area but varies with concentrations of workshops, traffic conditions, landforms and weather patterns. Research has it that evaporated fuel is also a pollutant and about a third of vehicle hydrocarbon emissions are from evaporation, which occurs when driving, during refueling, and even when stationary.

\section{h) Reduced Exercise and Recreation}

Regular aerobic exercise is essential to good health. A sedentary lifestyle has the cardiovascular risk equal to smoking 20 cigarettes a day. The most practical way to obtain this exercise is to encourage non-motorized transportation. Given suitable conditions, people walk and ride bicycle more than it occurs in automobile dependent communities. Residents will like to walk and cycle, but feel constrained by the existing traffic and land use conditions. This limitation agrees with the fifth condition of auto-dependent city by Litman, (2011). Mobility of personal travel by non-drivers compared with drivers is severely limited as non-driver are disadvantaged, first from the existing road designs that do not accommodate cycling and walking, then secondly by the risk of been knocked down. Consequently, a drop in the total amount of active transport. The use of streets as social, leisure and recreational arena or congregating spaces for the community event, is threatened and undeniably has been supplanted by the increasing and rapid automobile 
traffic flow common to the area. What passed for an early playground to let children play and have fun has disappeared. Presently not minding the tarred nature of the streets, children still play on it at their own risk.

\subsection{Solutions to Automobile Dependence In Cities: Four Key Policies}

Four key consideration of relevance to public policy on how to reduce automobile dependence include; Public Transport Infrastructure, Pedestrian/Cycle Orientation, Density and Planning and Control

\section{a) Public Transport Infrastructure}

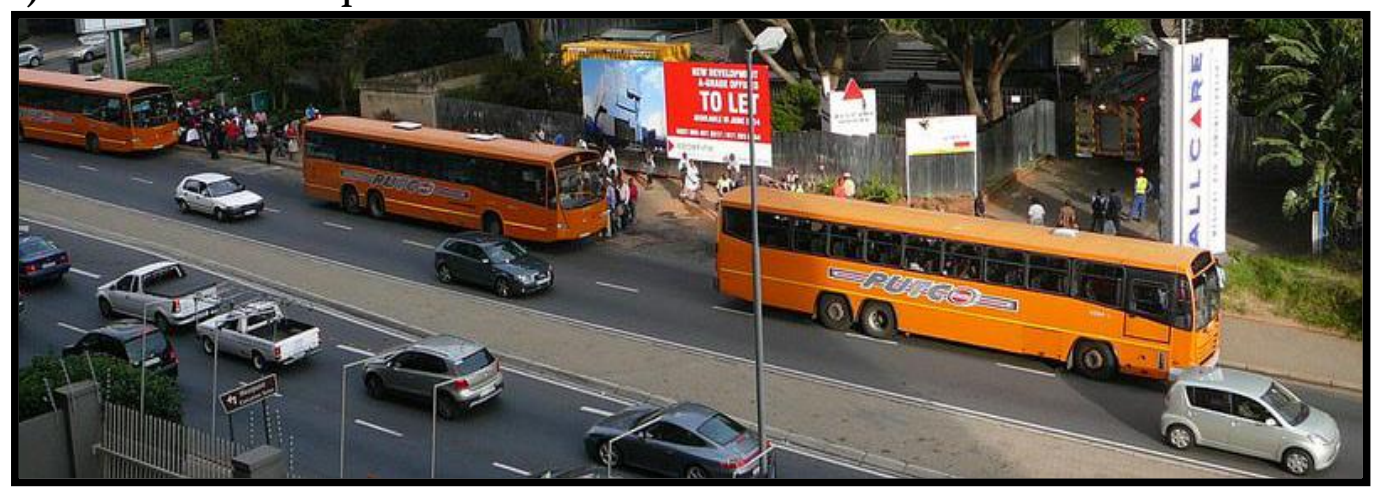

Figure 13; show public transport buses

Source; google

In developed cities where public transit system has been prioritized made available, convenient and attractive, residents are prone use them to meet their mobility needs. Investment in transit infrastructure can help shape the city as well as mitigate traffic issues. It is also possible to "upgrade" as demand increases and as cities expand in size and affluence - for example, as light trains or trams replace express buses. If public transit is left as a supplementary process in streets designed for the automobile, there will be no resolution of the transport dilemma our cities face. However, policies that may lead to an increase in the costs of owning a car should be developed and implemented.

\section{b) Pedestrian/Cycle Orientation}

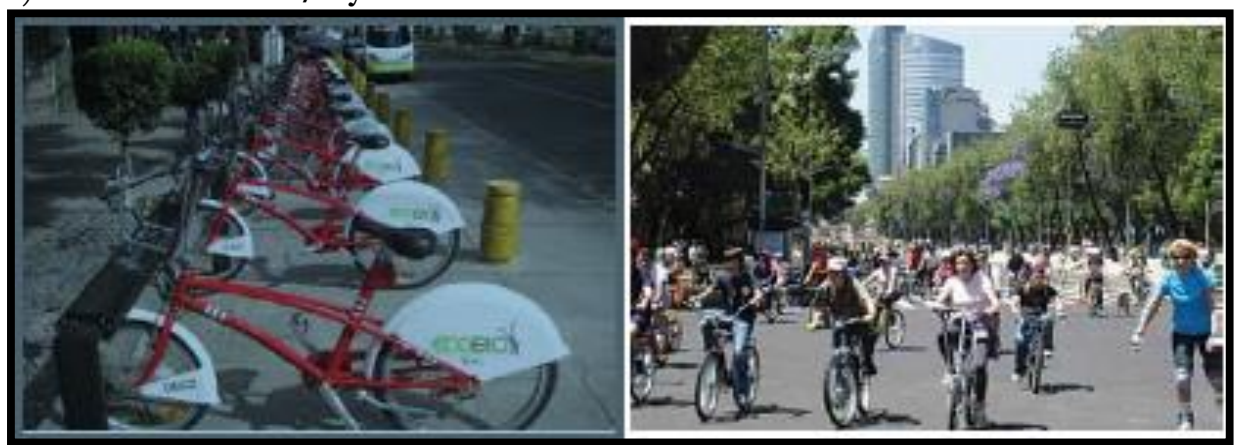

Figure 14; show cycle oriented city

Source; google 
Non-motorized transport is considered to have a lower status in many developing cities. If the goal is to provide for the most efficient, equitable and human form of transport, this means a city with provision for cycling, adequate walking space on streets and in public squares, and traffic-free shopping streets should be adopted and implemented. Any municipality that neglects this dimension will find social and economic problems as well as the apparent environmental issue, as is seen in most cities in Nigeria. Walking and cycling is a form a physical exercise needed for body growth and proper functioning of the muscles.

\section{c) Density}

The need to maintain land use efficiency is linked closely to transport. Dispersing land uses at low density creates automobile dependence. A dense urban village linked by public transit creates the opportunity for "walking city" and "transit city", this is a characteristics to be incorporated into the city based on the automobile. Similarly, bringing new and efficient public transit lines into rapidly growing cities may encourage the development of such dense urban settlements and restrict the spread of low density, especially where land use planning helps to encourage these developments

\section{d) Planning and Control}

All three of the above policies have strong market pressures behind them. But they also require planning to facilitate them. This planning is not heavy-handed bureaucracy but an expression of any city's cultural values - and also of the needs and priorities of pedestrians and cyclists and of children, youth and all other citizens who cannot or do not use cars. It highlights the priority on urbanity and on access to city services for all people. All cities have some commitment to this social value. If automobile dependence is not resisted through conscious planning, it will erode or help to destroy most attempts to maintain community life in an urban setting.

\subsection{Eco Mobility}

Eco-Mobility is a term used to describe travel through integrated, socially inclusive, and environmentally friendly transport options, including and integrating walking, cycling and wheeling. (Martin, 2016). It improves the quality of life of dwellers by allowing citizens meet their transportation needs in a sustainable manner, enhances travel options and promotes social cohesion. It is neither a new type of transport nor a common term for heterogeneous transport, but an environmentally sustainable and socially inclusive, ecological mobile transport choices that have low to zero emission compared to fossil-fuel-powered personal automobile. This advocates the use of light electric vehicles, given renewable energy sources are the source of electricity. 


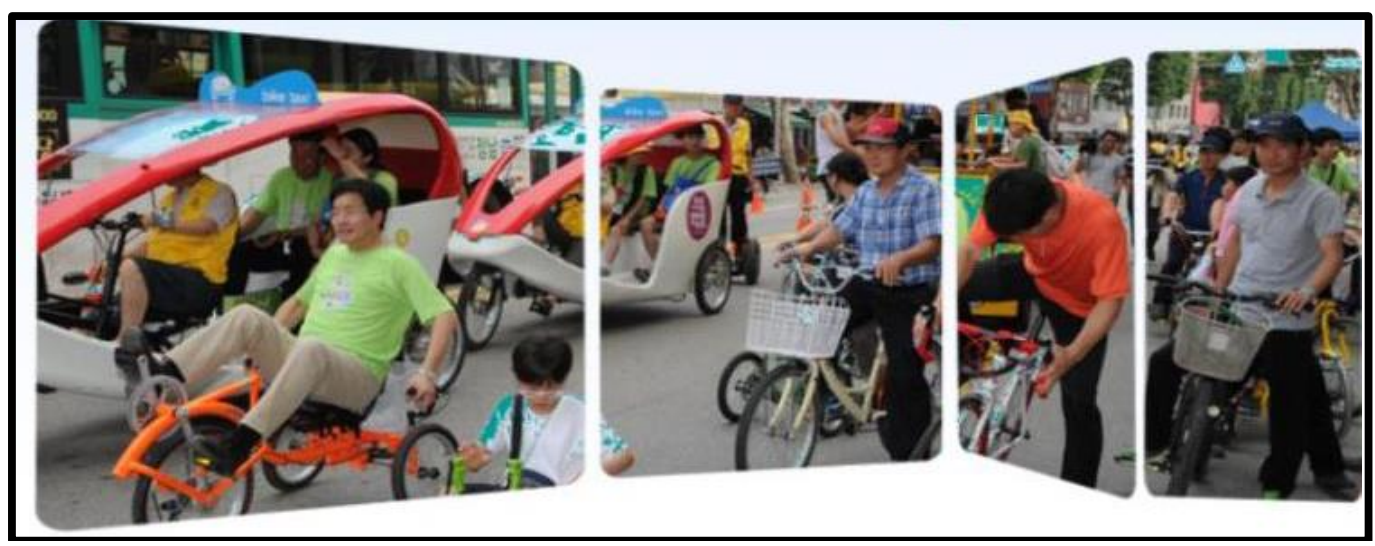

Figure 15; show means of Eco mobility

Source; Eco mobility World Festival, 2013

\section{Recommendation}

We need to discard renewal rhetoric and begin to insist on the concept that old uses may indeed be the best uses, particularly when they involve people living in cities. Social and commercial interplay, not separation of uses, makes cities into vital places for people. However, the three most preferred modes to help decrease automobile dependence are: cycling, walking and public transport. According to Clarke, (2003) promoting these alternatives to the car means: "we are again engaged in a process of change. This has profound implications for planning and design thinking at all levels; from how we think about the structure of towns and cities and where we locate new development right through to how we lay out individual street blocks and design the buildings within them".

Nevertheless, below are some recommendations.

- A good and functional urban transportation design has a pivotal role to play in reversing the view that public mass transits is just for second-class citizen. Therefore, proper Physical planning and subsequent reviews is necessary to ensure adequate choices and local accessibility of good quality are available.

- A fundamental change (extemporaneous or induced) from current value systems and choice behaviour is required through a new technological paradigm that provides better ways to meet mobility and access requirements of global and regional context in which we find ourselves.

- The government should ensure quality transit, bicycling and walking - to provide genuine options to the car;

- Urban villages - should develop multimodal centers with mixed, compact land use that reduce travel needs and are linked to high-quality transport systems;

- Growth management -by redirecting development into urban villages to prevent urban sprawl and revitalizing the central and inner cities;

- Increased transportation taxes - to offset expenditure and invest generated revenue as funds to develop a green municipality. 
- Improve telecommuting- this strategy will help reduce traffic cramps as workers conduct business using computers, internets and cell phones from their homes.

\section{Conclusion}

Cities are the nuclei of economic growth and development and this will increasingly and definitely be the case in the coming decades, as more than half of Enugu's population now live in the city. This number is expected to escalate due to the quest for a better life that has resulted to rural-urban migration. Doubtlessly cars have an enormous economic value, but the ill effect of its impact on the urban areas calls for urgent attention. It is naive and ahistorical to conclude that reliance on cars played an insignificant role in urban deterioration and suburban expansion, because this study has highlighted its linkage to urban decay. Although decay is not an inevitable process, but the result of neglect. Our city is in dire need of urban repair not urban removal because the destruction has gone far, and the issue today is saving the layout before the last testament to our predecessor's civility will disappear. The most imperative first step is to free our urban environment from the overwhelming burden of automobiles and the traffic structures necessary for their accommodation. The secret of this revitalization is reintegration as spelt out in the recommendations.

Bigger is not better, shinier is not nicer and a free parking place is not the ultimate good in a truly humanistic city plan. The most effective return to a sense of scale to the urban environment of Achara Layout is converting street spaces from cars to pedestrian use. This research however, does not dispute the major advantages that automobile offer, nor does it propose that urban architecture should become absolutely car-free. It only surmise that an ideal transportation system that affords travellers a combination of nonmotorized, motorized and public transport alternatives, with incentives to encourage users to choose the best option for each trip be implemented. This will result in an efficient and equitable transport system that maximizes benefits to users and society at large.

\section{Reference}

Chad, H. (2017) Annual General Meeting Royal Dutch Shell plc: Speeches by Chairman and CEO Royal Dutch Shell plc, The Hague, The Netherlands May 23, 2017

Clarke, P. (2003) 'Urban Planning \& Design', in Thomas, R. \& Fordham, M (eds) (2003) op. cit., p.14

Clay M, (1999). The origins and globalization of traffic control signals, Journal of Urban history, 25 (3) March 1999 pp 379-404

Gauzin-Müller, D. (2002) Sustainable Architecture and Urbanism - Concepts, Technologies, Examples, Birkhäuser, Basel, p.47.

Goodwin, P. (1997) Mobility and Car Dependence in Traffic and Transport Psychology, Theory, and Applications. New York: Pergamen Press.

Kenworthy, J. R. and Laube, F.B. (1999) Patterns of automobile dependence in cities: an international overview of key physical and economic dimensions with some implications for urban policy. Transportation Research Part A 33 (1999) 691-723

Litman, T. \& Laube, F., (2002). Automobile Dependency and Economic Development, Canada: Victoria Transport Policy Institute.

Litman, T. (2011) The First Casualty of a Non-Existent War: Evaluating Claims of Unjustified Restrictions on Automobile Use, and a Critique of 'Washingtons War On Cars and the Suburbs',Victoria 
Transport Policy Institute (http://www.vtpi.org); [ONLINE] Available at http://www.vtpi.org/carwars.pdf. [Accessed 2 September, 2017].

Mackett, R. (2002) Increasing Car Dependency of Children: Should We Be Worried? Proceedings of the Institution of Civil Engineers-Municipal Engineer, 151 (1) pp. 29-38.

Martin, C. (2016) Sustainable Mobility and climate change in Quebec [ONLINE] Available at https://www.solutionswill.com/en/blog_post/sustainable-mobility-and-climate-change-inquebec/ [Accessed 3 September, 2017].

Martin, V. M. (2010). the Automobile Shapes the City; Modifying the City Core [ONLINE] Available at http://www.autolife.umd.umich.edu/Environment/E_Casestudy/E_casestudy 4.htm [Accessed 23 August, 2017]

Matt, L. (2014) What is Auto-Dependency [ONLINE] Available at https://www.greaterauckland .org.nz/2014/01/10/what-is-auto-dependency/ [Accessed 2 September, 2017]

Newman, P. \& Kenworthy, J. (1999) Sustainability and Cities: Overcoming Automobile Dependence, Island Press, Washington, p.334.6

Okeke, F. O., Eziyi, I. O., Udeh, C. A., \& Ezema, E.C. (2020). City as Habitat: Assembling the fragile city. Civil engineering Journal 6(6) pp 1143-1154. doi: http://dx.doi.org/10.28991/ cej-2020-03091536

Okeke, F.O, Sam-Amobi, C and Okeke, F.I (2020) Role of local town planning authorities in building collapse in Nigeria: evidence from Enugu metropolis. Heliyon 6(7) https://doi.org/10.1016/j.heliyon.2020.e04361

Ronald, W. (1981). Cities for People; practical measures for improving urban environment. Published by Van Nostrand Reinhold Company New York. ISBN.0442294298

Stage, L., (2009). Transportation Research Part A: Policy and Practice. In: Car Use: Lust and Must. Instrumental, Symbolic and Affective Motives for Car Use, pp. 147- 162.

Thomas, R. (2003) 'Introduction' in Thomas, R \& Fordham, M. (eds) (2003) Sustainable Urban Design: An Environmental Approach, Spon Press, London, p.3. 5

Udeh, C.A. and Okeke, F.O. (2018) Urban Regeneration - Eradicating Urban Decay for Improved Human Settlement. Journal of Environmental Management \& Safety 9(1) pp 49- 54.

WHO. (2013) Road traffic deaths - World Health Organization [ONLINE] Available at www.who.int/gho/road_safety/mortality/en/ [Accessed 2 September, 2017]. 